\title{
Cation Exchange Capacity of Zeolite $X$ from Bagasse Ash against Magnesium(II)
}

\author{
Suci Amalia \\ Jurusan Kimia Fakultas Sains dan Teknologi Universitas Islam Negeri Maulana Malik Ibrahim Malang \\ Email: Amel_kimiaa@yahoo.com
}

\begin{abstract}
Water is a substance crucial for human life and industries. The good water must be fulfill some criteria, such as absence of $\mathrm{Ca}^{2+}$ or $\mathrm{Mg}^{2+}$ cations. The cations can be reduced by ion exchange process. This study used synthesized zeolite $\mathrm{X}$ from bagasse ash as cation exchange for $\mathrm{Mg}^{2+}$. Mg ion was used as standard to determine hardness of water by EDTA titration. The analysis showed cation exchange capacity of zeolite $\mathrm{X}$ with molar ratio of $\mathrm{Si} / \mathrm{Al} 1 ; 1,5$ and 2 was 1,9 . The value indicated zeolite $\mathrm{X}$ have high capability as cation absorbents for $\mathrm{Mg}^{2+}$ ion.
\end{abstract}

Keywords: bagasse ash, cation exchange capacity, magnesium(II), water hardness, zeolite X

\begin{abstract}
Abstrak
Sebagai kebutuhan pokok masyarakat dan industri, air bersih harus memenuhi persyaratan, baik secara fisik, kimia maupun bakteriologis. Salah satunya adalah bebas dari sifat sadah atau tidak ada kation $\mathrm{Ca}^{2+}$ dan $\mathrm{Mg}^{2+}$. Kation penyebab kesadahan dapat dikurangi atau dihilangkan salah satunya dengan proses pertukaran ion. Penelitian ini menggunakan zeolit $\mathrm{X}$ hasil sintesis dari abu ampas tebu untuk mengetahui efektifitasnya sebagai penukar kation logam $\mathrm{Mg}^{2+}$, sebagai tolak ukur untuk menurunkan kesadahan air menggunakan metode titrasi EDTA. Hasil analisis Kapasitas Tukar kation (KTK) menunjukkan bahwa zeolit X dengan rasio molar Si/Al 1; 1,5; dan 2 mempunyai efektifitas yang tinggi sebagai adsorben kation logam Mg. Kapasitas Tukar Kation (KTK) dari zeolit $\mathrm{X}$ dengan rasio molar 1; 1,5 dan 2 sebesar $\pm 1,9$.
\end{abstract}

Kata Kunci: Ampas tebu, kapasitas tukar kation, magnesium(II), kesadahan air, zeolit X

\section{Pendahuluan}

Air bersih merupakan salah satu kebutuhan pokok dalam kehidupan rumah tangga, industri dan tempat umum yang dibutuhkan secara berkelanjutan. Oleh karena itu, kebutuhan air bersih harus terpenuhi, baik secara kualitas maupun kuantitas agar tidak memberikan dampak negatif bagi kehidupan sosial dan ekonomi masyarakat. Pemenuhan kebutuhan air rumah tangga dan industri harus memenuhi persyaratan air bersih yaitu secara fisik, kimia dan bakteriologis.

Salah satu parameter kimia dalam persyaratan kualitas air adalah kesadahan air. Secara umum, kation yang sering menyebabkan air sadah adalah kation $\mathrm{Ca}^{2+}$ dan $\mathrm{Mg}^{2+}$. Kation ini dapat membentuk kerak apabila bereaksi dengan air sabun.
Sebenarnya, tidak ada pengaruh derajat kesadahan bagi kesehatan tubuh. Namun, kesadahan air dapat menyebabkan sabun atau deterjen tidak bekerja dengan baik (tidak berbusa). Berdasarkan PERMENKES RI Nomor 416 Tahun 1990, derajat kesadahan $\left(\mathrm{CaCO}_{3}\right)$ maksimum air yang layak minum adalah $500 \mathrm{mg}$ per liter (Yusuf, 2012). Penghilangan kesadahan air (pelunakan) dilakukan untuk menghilangkan atau mengurangi kation $\mathrm{Ca}^{2+}$ dan $\mathrm{Mg}^{2+}$. Kation penyebab kesadahan dapat dikurangi atau dihilangkan salah satunya dengan proses pertukaran ion.

Zeolit dapat digunakan sebagai penukar kation karena memiliki sejumlah sifat kimia tertentu. Zeolit merupakan hidrat alumino silikat yang memiliki 
struktur kerangka tiga dimensi dibentuk oleh $\mathrm{AlO}_{4}{ }^{5-}$ dan $\mathrm{SiO}_{4}{ }^{4-}$ dengan rongga terisi logam alkali dan alkali tanah serta dikelilingi oleh molekul air (Hamdan, 1992). Hal tersebut menyebabkan struktur berpori zeolit cukup luas, sehingga baik digunakan sebagai adsorben dan penukar ion. Penelitian ini menggunakan zeolit $\mathrm{X}$ hasil sintesis dari abu ampas tebu. Tujuan penelitian ini adalah untuk mengetahui efektifitas zeolit $\mathrm{X}$ hasil sintesis untuk penukar kation logam $\mathrm{Mg}^{2+}$ sebagai tolak ukur untuk menurunkan kesadahan air.

\section{Metode Penelitian}

\subsection{Alat dan Bahan}

Alat-alat yang digunakan dalam penelitian ini adalah seperangkat alat gelas, indikator $\mathrm{pH}$ universal, shaker, pengaduk magnet, spatula, termometer, hot plate, desikator, oven (Fischer Scientific), tanur (Fischer Scientific), corong buchner, neraca analitik (Mettler AE 160, Jerman), dan stopwatch.

Bahan yang digunakan dalam penelitian ini adalah ampas tebu sebagai sumber silika, akuades, aquadem, etilendiamintetraasetat (EDTA), buffer $\mathrm{pH}$ 10, indikator EBT (Eriochroma Black T), natrium hidroksida $(\mathrm{NaOH})$, aluminat $\left(\mathrm{Al}_{2} \mathrm{O}_{3}\right)$ sebagai sumber alumina, asam klorida $(\mathrm{HCl} 1 \mathrm{M})$, magnesium sulfat $\left(\mathrm{MgSO}_{4} .7 \mathrm{H}_{2} \mathrm{O}\right)$, dan kertas saring Whatman No.1. Sintesis zeolit $\mathrm{X}$ dari abu ampas tebu adalah hasil sintesis dari penelitian Asfadiyah (2014).

\subsection{Preparasi Sampel Logam Magnesium}

Sebanyak 0,2 gram $\mathrm{MgSO}_{4} \cdot 7 \mathrm{H}_{2} \mathrm{O}$ diencerkan dalam labu takar $1000 \mathrm{~mL}$ dengan aquadem. Konsentrasi logam $\mathrm{Mg}$ (II) dibuat dengan standar 200 ppm. Larutan $\mathrm{Mg}(\mathrm{II})$ yang akan dijadikan standar diukur kadar pH-nya dengan indikator $\mathrm{pH}$ universal.

\subsection{Aktivasi Zeolit $\mathrm{X}$ Hasil Sintesis dengan $\mathrm{NaCl} 3 \mathrm{M}$}

Zeolit $\mathrm{X}$ hasil sintesis dari abu ampas tebu dengan variasi rasio molar $\mathrm{Si} / \mathrm{Al} 1,1,5$ dan 2 masing-masing sebanyak 1 gram. Disiapkan larutan $\mathrm{NaCl} 3 \mathrm{M}$ sebanyak 9 $\mathrm{mL}$. Sesuai dengan perbandingan berat per volume yaitu 1:2 (gram: $\mathrm{mL}$ ), kemudian sampel masing-masing zeolit $\mathrm{X}$ dengan variasi rasio molar $\mathrm{Si} / \mathrm{Al} 1,1,5$ dan 2 direndam dengan larutan $\mathrm{NaCl} 33$. Campuran dipanaskan pada suhu konstan $100{ }^{\circ} \mathrm{C}$ selama 4 jam dan disertai pengadukan. Setelah itu zeolit yang masih panas dipisahkan menggunakan corong yang telah dilapisi kertas saring. Zeolit dibilas dengan aquadem sampai air bilasan bebas ion $\mathrm{Cl}^{-}$menggunakan indikator $\mathrm{AgNO}_{3}$. Selanjutnya, kadar $\mathrm{pH}$ zeolit aktivasi diukur kemudian sampel zeolit dikeringkan selama 2 jam dengan suhu 110 ${ }^{\circ} \mathrm{C}$.

\subsection{Penentuan Kapasitas Tukar Kation (KTK) Zeolit X terhadap Logam Magnesium(II)}

Proses penurunan kesadahan air dengan sampel buatan logam $\mathrm{Mg}^{2+}$ dengan konsentrasi 200 ppm menggunakan teknik batch, dimana dalam teknik ini akan diketahui efek waktu kontak penukaran kation. Sampel dengan volume rata-rata $100 \mathrm{~mL}$ dimasukkan ke dalam 15 erlenmeyer. Rasio zeolit X yang digunakan adalah rasio 1 ; 1,5 ; dan rasio 2 . Rasio zeolit $\mathrm{X}$ dan larutan $\mathrm{Mg}$ dibuat dengan perbandingan yaitu $0,5 \mathrm{~g}$ zeolit $\mathrm{X}: 100 \mathrm{~mL}$ larutan Mg. Variasi waktu yang dilakukan yaitu: 15, 30, 60, 90, 120 menit. Selanjutnya 15 erlenmeyer tersebut ditempatkan pada rotary shaker dengan kecepatan rata-rata 200 rpm pada suhu ruang dan dishaker sesuai dengan variasi waktu yang digunakan. Sampel selanjutnya disentrifuge selama 3 menit dengan 3000 rpm. Kemudian zeolit dipisahkan dari supernatan, setiap sampel disaring menggunakan kertas saring Whatman 
No.1. Selanjutnya $\mathrm{pH}$ setiap supernatan diukur. Selanjutnya sampel sebanyak 50 $\mathrm{mL}$ dimasukkan ke dalam erlenmeyer, pada sampel ditambahkan $5 \mathrm{~mL}$ buffer $\mathrm{pH}$ 10 dan sedikit indikator EBT. Kemudian sampel dititrasi dengan EDTA 0,1 M dan konsentrasi logam $\mathrm{Mg}$ yang tidak teradsorpsi dihitung. Untuk prosedur yang sama dilakukan pada zeolit $\mathrm{X}$ hasil aktivasi $\mathrm{NaCl}$.

\section{Hasil dan Pembahasan}

Tingkat kesadahan suatu air dapat diketahui salah satu caranya adalah dengan metode titrasi EDTA (etilendiamintetraasetat). Titrasi ini banyak digunakan di laboratorium untuk penentuan kesadahan air terutama analisis adanya ion $\mathrm{Ca}^{2+}$ dan $\mathrm{Mg}^{2+}$. Titrasi ini dapat diukur langsung dengan EDTA sebagai agen titrasi pada $\mathrm{pH} 10$ yang menggunakan indikator EBT (Eriochroma Black T). Sifat yang sangat penting dan khas dari senyawa EDTA adalah kemampuannya membentuk senyawa kompleks kelat (sepit) bertangan banyak. Berdasarkan sifat zeolit yang dapat mengadsorbsi dan sebagai penukar ion logam-logam yang ada dalam air, maka logam-logam dalam air akan diketahui berdasarkan nilai yang ekivalen dengan titrasi EDTA, namun dalam penelitian ini hasil yang dianalisis hanya logam $\mathrm{Mg}$ (II) yang tidak teradsorpsi pada zeolit $\mathrm{X}$.

Aktivasi zeolit $\mathrm{X}$ dengan $\mathrm{NaCl}$ dilakukan dengan tujuan untuk meregenerasi kation-kation yang ada di permukan zeolit $\mathrm{X}$ dengan logam natrium. Zeolit $\mathrm{X}$ belum bisa dianggap sepenuhnya $\mathrm{Na}$-Zeolit X, walaupun bahan baku zeolit $\mathrm{X}$ adalah $\mathrm{NaOH}$. Akan tetapi karena bahan baku sumber silika yang berasal dari abu ampas tebu masih mengandung pengotor logam-logam lain, maka perlu dilakukan penyeragaman kation penyeimbang pada zeolit supaya zeolit $\mathrm{X}$ bekerja lebih optimal. Keunggulan zeolit sebagai bahan penukar kation yaitu mempunyai sistem yang kompak sehingga mudah dioperasikan dan dapat dipakai berulang kali.

Berdasarkan hasil analisis perhitungan dengan mengkonversi jumlah mmol EDTA yang terukur setara dengan jumlah mmol ion $\mathrm{Mg}^{2+}$, diperoleh data seperti yang disajikan pada Tabel 1 dan 2 . Sampel buatan logam magnesium yang digunakan semula adalah 200 ppm atau $200 \mathrm{mg} / \mathrm{L}$. Akan tetapi setelah diuji secara kuantitatif dengan titrasi EDTA, kadar logam Mg menjadi $243 \mathrm{ppm}$ atau 243 mg/L. Berdasarkan kadar logam magnesium yang teradsorp pada zeolit $\mathrm{X}$ dan zeolit Na-X, atau dilihat dari jumlah logam Magnesium(II) yang membentuk kompleks dengan ligan EDTA menunjukkan bahwa zeolit $\mathrm{X}$ dan zeolit $\mathrm{Na}-\mathrm{X}$ dengan rasio molar $\mathrm{Si} / \mathrm{Al} \mathrm{1;} \mathrm{1,5;} \mathrm{dan}$ 2 mempunyai efektifitas yang tinggi sebagai adsorben kation logam $\mathrm{Mg}$.

Pengaruh variasi efek waktu kontak ion exchange logam Mg pada penelitian ini menunjukkan bahwa kapasitas tukar kation (KTK) pada zeolit X dan zeolit Na-X telah jenuh untuk mengadsorp logam magnesium. Akibatnya dengan variasi waktu kontak zeolit $\mathrm{X}$ dan zeolit Na-X menunjukkan harga Kapasitas Tukar Kation (KTK) dari zeolit X dan zeolit Na$\mathrm{X}$ dengan rasio molar 1, 1,5 dan 2 sebesar $\pm 1,9$. Untuk memastikan berapa waktu kontak optimum zeolit X dan zeolit Na-X sebagai ion exchange logam $\mathrm{Mg}$, maka perlu dilakukan analisis waktu kontak zeolit X dengan larutan $\mathrm{Mg}$ (II) sebelum 15 menit yaitu dari 0-15 menit.

Hasil analisis kapasitas tukar kation tersebut diketahui bahwa zeolit $\mathrm{X}$ dan zeolit $\mathrm{Na}-\mathrm{X}$ dengan rasio molar $\mathrm{Si} / \mathrm{Al} 2$ mempunyai efektifitas mengadsorp logam $\mathrm{Mg}$ lebih baik dibandingkan zeolit $\mathrm{X}$ dan zeolit $\mathrm{Na}-\mathrm{X}$ dengan rasio molar $\mathrm{Si} / \mathrm{Al} 1$ dan 1,5 meskipun harga Kapasitas Tukar Kation (KTK) dari ketiga zeolit $\mathrm{X}$ dan zeolit $\mathrm{Na}-\mathrm{X}$ yang digunakan tidak berbeda 
secara signifikan. Hal ini menunjukkan bahwa semakin tinggi tingkat kristalinitas dari zeolit $\mathrm{X}$ hasil analisis XRD dan semakin besar ukuran luas permukaan zeolit $\mathrm{X}$, maka efektifitas untuk adsorpsi logam magnesium semakin besar.

Tabel 1. Kadar $\mathrm{Mg}$ yang terukur dari adsorben zeolit $\mathrm{X}$ dengan variasi rasio molar $\mathrm{Si} / \mathrm{Al}$ dan variasi waktu kontak

\begin{tabular}{cccccc}
\hline No. & $\begin{array}{c}\text { Rasio } \\
\text { Zeolit X }\end{array}$ & $\begin{array}{c}\text { Lama } \\
\text { Pengadukan } \\
\text { (menit) }\end{array}$ & $\begin{array}{c}\text { Warna Sampel } \\
\text { Saat Proses } \\
\text { Adsorpsi }\end{array}$ & $\begin{array}{c}\text { Kadar Logam Mg } \\
\text { Terukur EDTA } \\
(\mathbf{p p m})\end{array}$ & $\begin{array}{c}\text { KTK } \\
\text { Zeolit X }\end{array}$ \\
\hline & & 15 & Keruh & 29,2 & 1,92 \\
& & 30 & Keruh & 48,8 & 1,88 \\
1. & 1 & 60 & Bening & 68 & 1,84 \\
& & 90 & Bening & 29,2 & 1,92 \\
& 120 & Bening & 38,8 & 1,90 \\
& 15 & Keruh & 24,32 & 1,93 \\
& & 30 & Keruh & 63,24 & 1,85 \\
2. & 60 & Bening & 14,6 & 1,95 \\
& 1,5 & 90 & Bening & 38,92 & 1,90 \\
& & 120 & Bening & 19,44 & 1,94 \\
& & 15 & Keruh & 19,46 & 1,94 \\
& & 30 & Keruh & 19,46 & 1,94 \\
3. & 60 & Bening & 19,46 & 1,94 \\
& & 90 & Bening & 14,59 & 1,95 \\
& & 120 & Bening & 24,32 & 1,93 \\
\hline
\end{tabular}

Tabel 2. Kadar Mg yang terukur dari adsorben zeolit $\mathrm{Na}-\mathrm{X}$

\begin{tabular}{cccccc}
\hline $\begin{array}{c}\text { No. } \\
\text { Zeolit Na- } \\
\mathbf{X}\end{array}$ & $\begin{array}{c}\text { Lama } \\
\text { Pengadukan } \\
\text { (menit) }\end{array}$ & $\begin{array}{c}\text { Warna Sampel } \\
\text { Saat Proses } \\
\text { Adsorpsi }\end{array}$ & $\begin{array}{c}\text { Kadar Logam Mg } \\
\text { Terukur EDTA } \\
(\mathbf{p p m})\end{array}$ & $\begin{array}{c}\text { KTK Zeolit } \\
\text { Na-X }\end{array}$ \\
\hline \multirow{2}{*}{1.} & 1 & 60 & Bening & 24,50 & 1,93 \\
& & 120 & Bening & 12,00 & 1,95 \\
2. & 1,5 & 60 & Bening & 9,00 & 1,96 \\
& & 120 & Bening & 12,00 & 1,95 \\
3. & 2 & 60 & Bening & 6,00 & 1,96 \\
& & 120 & Bening & 9,00 & 1,96 \\
\hline
\end{tabular}

Hasil karakterisasi XRD dari penelitian Asfadiyah (2014) menunjukkan bahwa semakin tinggi rasio molar $\mathrm{Si} / \mathrm{Al}$ maka kristalinitas zeolit $\mathrm{X}$ semakin tinggi dengan puncak yang semakin runcing. Hasil analisis luas permukaan menggunakan metode adsorpsi metilen blue menunjukkan nilai luas permukaaan zeolit $\mathrm{X}$ rasio $1 ; 1,5$ dan 2 berturut-turut adalah 16,9967; 19,1037; dan 20,5449 $\mathrm{m}^{2} / \mathrm{g}$. Berdasarkan penelitian Asfadiyah (2014), menunjukkan zeolit X dengan rasio molar Si/Al 2 lebih baik dibandingkan zeolit dengan rasio molar Si/Al lainnya, akibatnya efektifitas zeolit $\mathrm{X}$ dengan rasio molar Si/Al 2 lebih baik sebagai bahan ion exchange. 


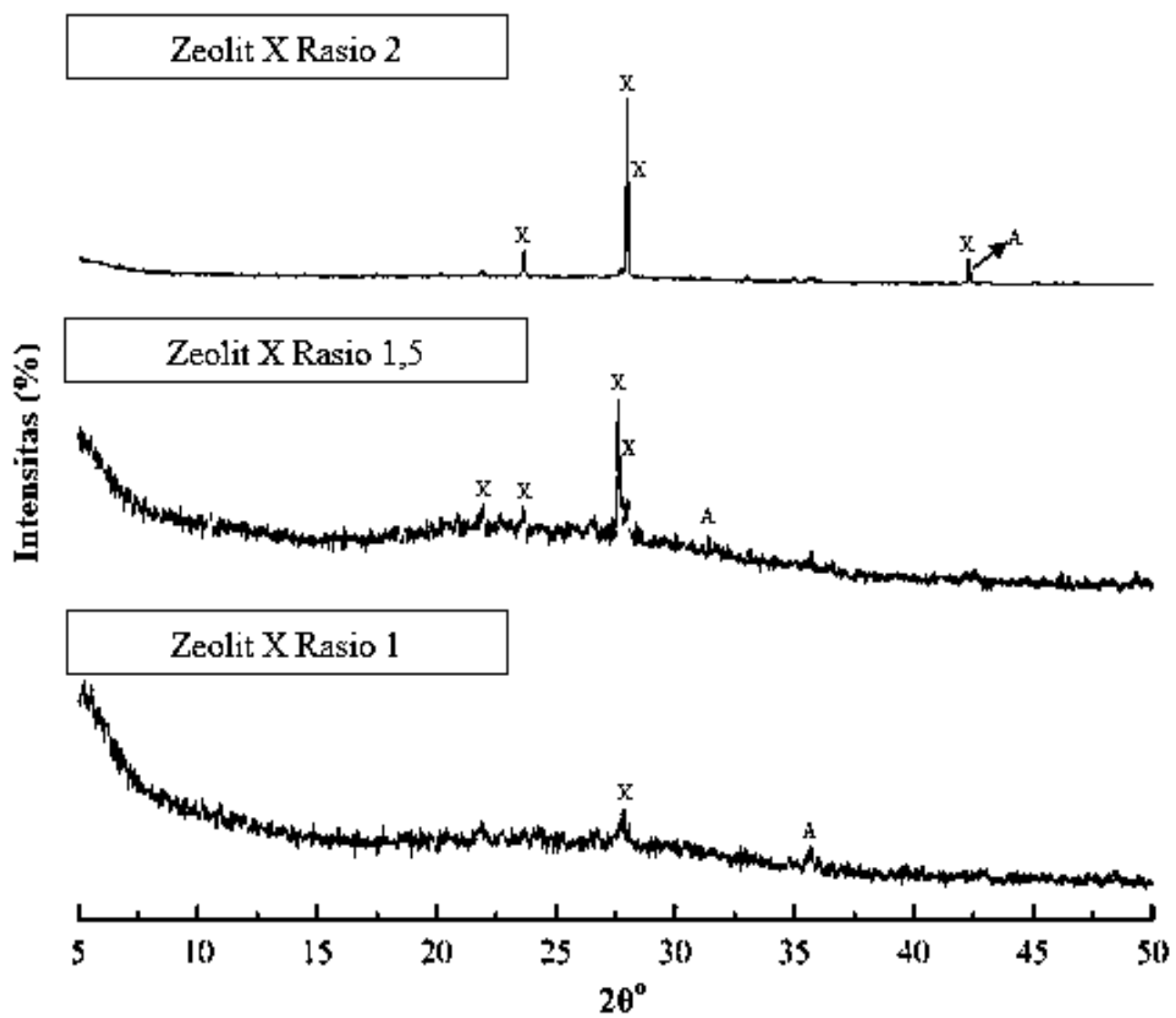

Gambar 1. Difraktogram zeolit X rasio molar Si/Al 1; 1,5 dan 2 (Asfadiyah, 2014)

\section{Kesimpulan}

Hasil analisis Kapasitas Tukar Kation (KTK) zeolit X dan zeolit $\mathrm{Na}-\mathrm{X}$ dari abu ampas tebu terhadap logam $\mathrm{Mg}^{2+}$ yaitu dengan mengukur kadar logam magnesium yang tidak teradsorpsi pada zeolit $\mathrm{X}$ menunjukkan bahwa kedua zeolit dengan rasio molar $\mathrm{Si} / \mathrm{Al} 1$; 1,5 ; dan 2 mempunyai efektifitas yang tinggi sebagai adsorben kation logam Mg. Kapasitas Tukar Kation (KTK) dari zeolit X dan zeolit Na-X dengan rasio molar 1, 1,5 dan 2 berada diantara kisaran sebesar $\pm 1,9$.

\section{Daftar Pustaka}

Asfadiyah, N. R. 2014. Sintesis dan Karakterisasi Zeolit $\mathrm{X}$ dari Abu Ampas Tebu dengan Variasi Rasio Molar Si/Al menggunakan Metode Sol-Gel. Skripsi. Malang: Universitas
Negeri Maulana Malik Ibrahim Fakultas Sains dan Teknologi Jurusan Kimia.

Hamdan, H. 1992. Introduction to Zeolite: Synthesis, Characterization and Modification. UTM Malaysia. pp 7080.

Hanafi, S. dan Nandang, R. 2010. Studi Pengaruh Bentuk Silika dari Abu Ampas Tebu terhadap Kekuatan Produk Keramik. Jurnal Kimia Indonesia. Vol. 5(1).

Masoudian, S.K., Sadighi, S., dan Abbasi, A. 2013. Synthesis and Characterization of High Aluminum Zeolite X from Technical Grade Materials. Bulletin of Chemical Reaction Engineering \& Catalysis. 8 (1). 54 - 60. Iran: RIPI. 
ALCHEMY: Journal of Chemistry, Vol. 4 No. 2 Oktober 2015, hal 107-112

Yusuf, Y. 2012. Teknologi Pengolahan Air Tanah sebagai Sumber Air Minum pada Skala Rumah Tangga. Sigma Journal. Vol 4 (2). 